\title{
Ocena nabycia wybranych kompetencji przedmiotowych nauczycieli geografii oraz studentów-kandydatów na nauczycieli
}

\author{
The assessment of selected subject competences \\ acquired by geography teachers and student-candidates for teaching posts
}

\section{WIKTOR OSUCH}

Instytut Geografii, Uniwersytet Pedagogiczny im. KEN, 30-084 Kraków, ul. Podchorążych 2; wikosuch@ap.krakow.pl

Zarys treści. Autor niniejszego opracowania od kilkunastu lat prowadzi badania dotyczące kształtowania kompetencji przedmiotowych i dydaktycznych studentów geografii-kandydatów na nauczycieli. Nabycie przez nich odpowiednich kompetencji stanowi najważniejszy element w profesjonalnym przygotowaniu przyszłego nauczyciela, $w$ tym nauczyciela geografii. $\mathrm{W}$ badaniach proszono o samoocenę poszczególnych kompetencji zarówno nauczycieli geografii, jak i studentów geografii-kandydatów na nauczycieli, a następnie podjęto próbę określenia zależności pomiędzy nabytymi kompetencjami nauczycieli a oceną prowadzonych lekcji przez studentów geografii.

Słowa kluczowe: kompetencje przedmiotowe, nauczyciel geografii, badania ankietowe, korelacje ocen.

\section{Wstęp}

W ostatnich latach w europejskim systemie szkolnictwa wyższego wprowadzono istotne zmiany wynikające z założeń Deklaracji Bolońskiej. W Polsce nastąpiły (i nadal następują) zmiany organizacyjne i programowe w uczelniach wyższych. Wydaje się ważne określenie wpływu tych zmian na kształtowanie i nabycie kompetencji przedmiotowych i dydaktycznych przyszłych nauczycieli i przygotowanie ich do pracy. Publikowany artykuł zawiera wyniki badań i rozważania na temat kompetencji przedmiotowych i dydaktycznych nauczycieli geografii oraz kandydatów na nauczycieli, szczegółowo opisane w monografii (Osuch, 2010).

Współcześnie zadania i obowiązki nauczyciela rozumiane są inaczej niż kilkadziesiąt lat temu. Nauczyciel - to człowiek dokształcający się na różnego typu studiach podyplomowych i kursach, zdobywający kolejne stopnie awansu 
zawodowego, co pozwala mu na nieznacznie wyższe zarobki i pewniejszą, stabilniejszą sytuację na rynku pracy. Ta sytuacja nie daje jednak pełnego bezpieczeństwa ani poczucia docenienia i dowartościowania z wykonywanej pracy. Ważne, aby w kolejnych latach wykształcić, zatrzymać i przekonać do zawodu nauczycielskiego wartościowych młodych ludzi. Istotnym kryterium w ocenie pracy nauczyciela jest uzyskany stopień awansu zawodowego, w praktyce jednak stopień awansu nie zawsze odzwierciedla posiadane umiejętności. Konieczna wydaje się zatem ich ocena. Oceny takiej nie może dokonać uczeń, bowiem byłaby nierzetelna i prawdopodobnie nieobiektywna. Autor niniejszego artykułu zaproponował zatem ocenę nauczyciela przez studentów, którzy odbywali praktykę w szkole pod opieką nauczyciela, a także samoocenę nauczyciela w zakresie nabytych kompetencji, zakładając, że będzie przeprowadzona rzetelnie i obiektywnie.

\section{Metody badań}

Jedną z metod wykorzystanych w badaniach kompetencji była metoda sondażu diagnostycznego, zwana też metodą ankietową, a narzędziem badawczym był kwestionariusz ankiety, zawierający pytania zamknięte, wyboru jednokrotnego i wielokrotnego. Badania przeprowadzono zarówno wśród nauczycieli geografii - opiekunów praktyk zawodowych, jak i studentów. W badaniach wzięło udział 96 nauczycieli geografii (2008-2009), absolwentów nauczycielskich studiów geograficznych Uniwersytetu Pedagogicznego w Krakowie, Uniwersytetu Jagiellońskiego, a także w nielicznych przypadkach Uniwersytetu Śląskiego, Uniwersytetu Mikołaja Kopernika w Toruniu i Uniwersytetu Marii Curie-Skłodowskiej w Lublinie. Ponadto do celów porównawczych dokonano oceny nabycia kompetencji przez 136 studentów geografii trzech różnych typów studiów Uniwersytetu Pedagogicznego w Krakowie.

Do wyliczenia korelacji pomiędzy badanymi zmiennymi posłużono się rozkładem t-Studenta z n-2 stopniami swobody, a także porównano wartość zaobserwowaną współczynnika korelacji liniowej $r$ z wartością krytyczną $r_{\alpha}$, obliczoną na podstawie wzoru (Greń, 1974). Do wyliczenia korelacji posłużono się programem komputerowym Mathematica 5.2 (for student) Wolframa. Korelację liniową $r$ wyliczono na podstawie wzoru:

$$
r=\frac{\sum_{i=1}^{n}\left(x_{i}-\bar{x}\right)\left(y_{i}-\bar{y}\right)}{\sqrt{\sum_{i=1}^{n}\left(x_{i}-\bar{x}\right)^{2} \sum_{i=1}^{n}\left(y_{i}-\bar{y}\right)^{2}}}
$$




\section{Przegląd literatury}

Istnieje wiele definicji (i ich interpretacji) kompetencji w ujęciu zawodu nauczycielskiego. Pedagodzy, dydaktycy oraz pedeutolodzy uważają, że kompetencje trudno ująć w jednoznaczną definicję. W niniejszym opracowaniu autor ograniczył się zaprezentowania niewielkiej liczby definicji i interpretacji kompetencji, jak również ich klasyfikacji i podziałów, głównie ze względu na utylitarny charakter publikacji.

Według W. Okonia (2001, s. 129) kompetencja nauczyciela to „zdolność nauczyciela do sterowania własnym zachowaniem według określonych sposobów wewnątrz sytuacji społecznej, w celu wytworzenia efektów empirycznie sprawdzalnych i aprobowanych przez tych członków środowiska, w którym funkcjonuje nauczyciel". Natomiast H. Kwiatkowska rozumie termin kompetencje jako „[...] zdolność i gotowość podmiotu do wykonania zadań na określonym poziomie; powstaje w wyniku zintegrowania wiedzy, dużej liczby drobnych umiejętności oraz sprawności w dokonywaniu wartościowań" (2008, s. 35).

Podział profesjonalnych kompetencji nauczycieli Ch. Kyriacou (1991) na: specjalistyczne (przedmiotowe), psychodydaktyczne, komunikacyjne, organizacyjne i kierownicze, diagnostyczne i interwencyjne, kompetencje w zakresie refleksji nad własną działalnością, stał się inspiracją dla kolejnych autorów i dalszych badań dotyczących kompetencji nauczycieli.

Czeski pedeutolog J. Průcha (2006, s. 306) definiuje kompetencje nauczycielskie jako „zbiór profesjonalnych umiejętności, wiedzy, wartości oraz postaw, którymi musi dysponować każdy nauczyciel, aby mógł efektywnie wykonywać swoją pracę".

Ch. Vielhaber (2006) pisał o klasyfikacji kompetencji i sylwetce absolwenta studiów geograficznych Uniwersytetu w Wiedniu. Autor mało uwagi poświęcił kompetencjom przedmiotowym z geografii, eksponując kompetencje w zakresie kooperacji i współpracy, motywacji do działania, planowania, refleksji nad własnym działaniem i wprowadzania innowacji. W kolejnej publikacji (Vielhaber, 2008) odniósł się do dyskusji na temat standardów kształcenia studentów geografii oraz kompetencji, powołując się także na definicje innych autorów, np. J. Erpenbecka i L. Rosenstiela (2003), a nawet modyfikując je. Był to wstęp do dyskusji na temat relacji pomiędzy standardami a kompetencjami, co student geografii powinien, a co musi umieć. W tym przypadku kompetencje przedmiotowe z geografii stanowiły najważniejszy element w podjętej dyskusji.

H. De Jong (2008) pisał o kształceniu studentów geografii-kandydatów na nauczycieli w Holandii. Oprócz analizy programów kształcenia geografów i praktyk w szkole, opisał sylwetkę absolwenta oraz jego kompetencje. Kompetencje podzielił na: komunikacyjne, pedagogiczne, specjalistyczne i dydaktyczne, organizacyjne, w zakresie współpracy z nauczycielami, rodzicami, w zakresie 
refleksji i profesjonalnego rozwoju. Kompetencje przedmiotowe z geografii De Jong połączył w rozbudowaną grupę razem z kompetencjami dydaktycznymi, co wydaje się uzasadnione.

Według Rozporządzenia MENiS z dnia 7 września 2004 r. (poz. 2110) w sprawie standardów kształcenia, przygotowanie do zawodu nauczyciela powinno prowadzić do nabycia kompetencji w następujących zakresach:

- dydaktycznym;

- wychowawczym i społecznym - związanym z umiejętnością rozpoznawania potrzeb ucznia oraz zdolnością do współpracy w różnorodnych relacjach międzyludzkich;

- kreatywnym - wyrażającym się zdolnością do samokształcenia, innowacyjnością i niestandardowością działań w powiązaniu ze zdolnościami;

- prakseologicznym - związanym ze skutecznością w planowaniu, realizacji, organizowaniu, kontroli i ocenie procesów edukacyjnych;

- komunikacyjnym - wyrażającym się skutecznością zachowań werbalnych i pozawerbalnych w sytuacjach edukacyjnych;

- informacyjno-medialnym - polegającym na umiejętności korzystania z technologii informacyjnych i komunikacyjnych oraz ich stosowania w nauczaniu; - językowym - w postaci znajomością co najmniej jednego języka obcego w stopniu zaawansowanym.

Spośród formalnych oczekiwań kompetencji, zapisanych bardzo ogólny w cytowanym Rozporządzeniu, autor wybrał do analizy tylko te, które wydały się ważne w profesjonalnym wykształceniu przyszłego nauczyciela geografii. Mało precyzyjny zapis skłonił do znacznego poszerzenia pola badawczego i opracowania szczegółowego wykazu kompetencji oraz przyjęcia innego ich podziału. Zaproponowano podział kompetencji na przedmiotowe z geografii, psycho-dydaktyczne (podzielone na dydaktyczne w zakresie dydaktyki geografii oraz pedagogiki opiekuńczo-wychowawczej) i kompetencje w zakresie prawa oświatowego. Niektóre spośród wymienionych w ministerialnym akcie prawnym kompetencji są ujęte w rozbudowanej grupie kompetencji dydaktycznych (Osuch, 2010).

\section{Wyniki badań}

Kwestionariusz ankiety, skonstruowany na podstawie obowiązujących standardów nauczania geografii w gimnazjum i liceum, składał się z czterech części, z których każda dotyczyła innej grupy kompetencji. Prezentowane kompetencje autor publikacji traktuje jako umiejętności. Poziom nabycia kompetencji był oceniany przez nauczycieli w skali 1-5 pkt., gdzie 1 oznacza brak, a 5 nabycie pełnych kompetencji w tym obszarze. 
Zbiorczą tabelę wybranych kompetencji przedmiotowych prezentuje Załącznik 1. W artykule ograniczono się do analizy i komentarzy tylko niektórych kompetencji.

Odnośnie do kompetencji przedmiotowych z geografii duża część nauczycieli geografii i w gimnazjum, i w liceum, uzyskała odpowiedzi 5 pkt. i 4 pkt., co można przełożyć na oceny bardzo dobre i dobre. Podobne, wysokie wyniki uzyskali studenci geografii studiów stacjonarnych. Na przykład, kompetencje związane z posługiwaniem się mapą, a dotyczące orientowania mapy (ryc. 1) i dokonywania rożnych obliczeń na podstawie map, w zdecydowanej większości oceniono najwyżej (5 pkt.). Uzyskano od kilku do kilkunastu (a nawet 27\% wśród nauczycieli gimnazjum i 25\% nauczycieli liceum) procent odpowiedzi wskazujących na ocenę dobrą (4 pkt.), co można uznać za dopuszczalne w licznej grupie nauczycieli o zróżnicowanym stażu pracy. 27\% nauczycieli gimnazjum i 25\% nauczycieli liceum nie wykorzystało okazji do częstego dokonywania pomiarów wysokości, stąd tylko ocena dobra (4 pkt.) w zakresie nabycia tej kompetencji.

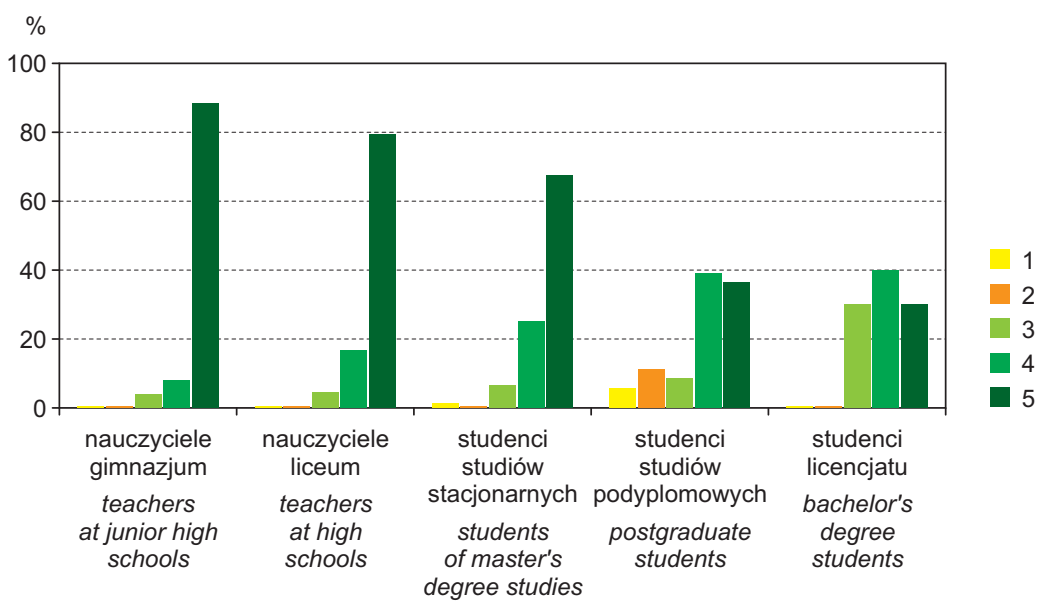

Ryc. 1. Ocena kompetencji w zakresie orientowania mapy

The assessment of competences in map orientation Źródło/Source: Osuch (2010, s./p. 112).

Umiejętność rysowania planów, szkiców i profili terenowych (ryc. 2) na ocenę bardzo dobrą wykształciło około 52\% ankietowanych nauczycieli gimnazjum, aż 35\% przyznało, że na ocenę dobrą (4 pkt.) i około 10\% na ocenę dostateczną (3 pkt.). Pomimo znacznej możliwości kształcenia tej umiejętności w czasie studiów nie wszyscy nauczyciele wykorzystują je w praktyce. Tę samą kompetencję na ocenę bardzo dobrą nabyło około $42 \%$ ankietowanych nauczycieli liceum, $46 \%$ na ocenę dobrą i około $12 \%$ na dostateczną. Są to wyniki znacznie gorsze 
niż nauczycieli gimnazjum. Prawdopodobnie wśród respondentów była duża grupa nauczycieli, którzy nie mają zdolności do rysowania i nieczęsto posługują się rysunkiem w pracy z młodzieżą. Ponadto są nauczyciele licealni, którzy rzadko prezentują własne rysunki na tablicy - znacznie częściej korzystają z obrazów schematycznych, realistycznych czy symbolicznych na planszach, w podręcznikach i atlasach. Studenci geografii studiów stacjonarnych nabyli umiejętność rysowania planów, szkiców i profili terenowych w większości (prawie 48\%) na ocenę dobrą, 30\% na bardzo dobrą, a ponad 16\% na dostateczną. Podobnie jak wśród nauczycieli geografii, jest grupa studentów, którzy nie mają zdolności swobodnego i biegłego posługiwania się rysunkiem, dlatego wyniki uzyskane dla tej umiejętności są nieco gorsze. Około 34\% studentów studiów podyplomowych nie nabyło tej kompetencji, a ok. 30\% z nich jest kompetentnych w zakresie rysowania planów, szkiców i profili terenowych w stopniu przynajmniej dobrym. Wśród studentów niestacjonarnych dominują oceny dobre.

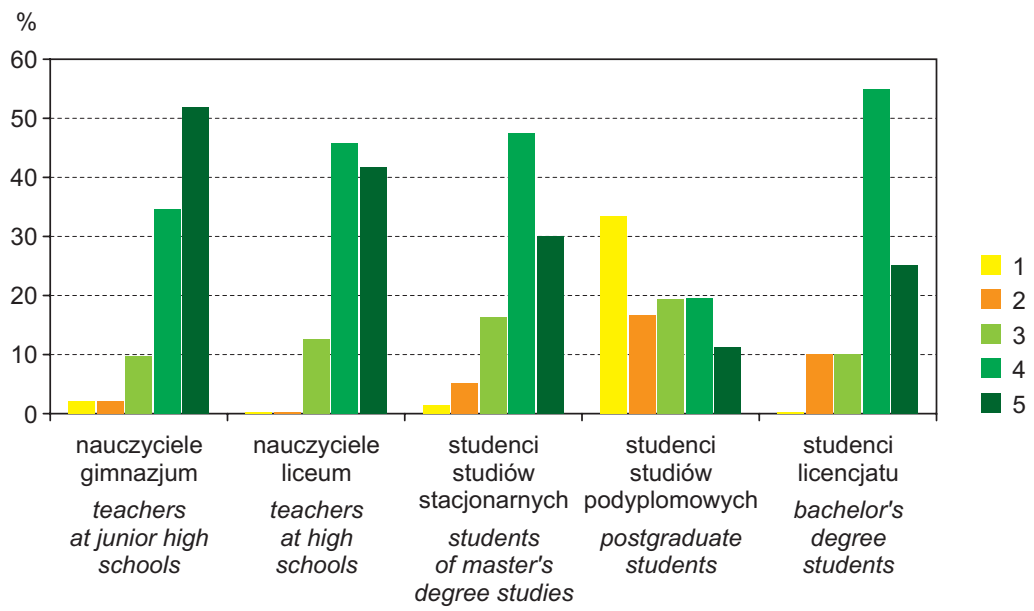

Ryc. 2. Ocena kompetencji w zakresie rysowania planów, szkiców i profili terenowych

The assessment of competences in drawing terrain plans, sketches and profiles Źródło/Source: Osuch (2010, s./p. 113).

Kompetencje w zakresie astronomicznych podstaw geografii (tab. 1) zostały wykształcone przez nauczycieli gimnazjum i liceum w większości na ocenę bardzo dobrą (5 pkt.). Wykonywanie rysunków przedstawiających widome drogi Słońca nad horyzontem w różnych szerokościach geograficznych prawie 31\% nauczycieli gimnazjum opanowało na ocenę dobrą, a prawie 6\% na dostateczną; nauczycieli liceum prawie 48\% na ocenę dobrą i niemal 13\% na dostateczną. Wśród studentów studiów stacjonarnych było blisko 23\% ocen dostatecznych, $18 \%$ dopuszczających, a tylko 22\% bardzo dobrych. Najsłabsze wyniki uzyskali 
studenci studiów podyplomowych, co wynika z braku przedmiotu ,astronomiczne podstawy geografii" w planie studiów.

Pewne problemy sprawiło nauczycielom gimnazjum opanowanie umiejętności z zakresu rozumienia praw ewolucji wszechświata i Ziemi (ryc. 3): 42\% z nich zaznaczyło ocenę dobrą i prawie 8\% dostateczną, a wśród nauczycieli liceum oceny były nieznacznie niższe (15\% dostatecznych, a 10\% wystawiło tylko 2 pkt.). Również studenci studiów stacjonarnych nabyli te kompetencje w słabym stopniu (20\% ocen dostatecznych, 10\% dopuszczających i tylko 25\% bardzo dobrych). Studenci studiów podyplomowych uzyskali nieco lepsze wyniki w zakresie nabycia tej kompetencji od studentów studiów licencjackich niestacjonarnych. W grupie studentów podyplomowych liczni byli biolodzy, którzy umiejętności te nabyli prawdopodobnie jeszcze na studiach kierunkowych z biologii. Studenci studiów niestacjonarnych uzyskali generalnie bardzo słabe (w stosunku do studentów stacjonarnych) wyniki w zakresie całej grupy kompetencji z astronomicznych podstaw geografii - dominują oceny dostateczne, a znaczny udział mają nawet dopuszczające (2 pkt.) wśród wszystkich kompetencji z zakresu astronomicznych podstaw geografii.

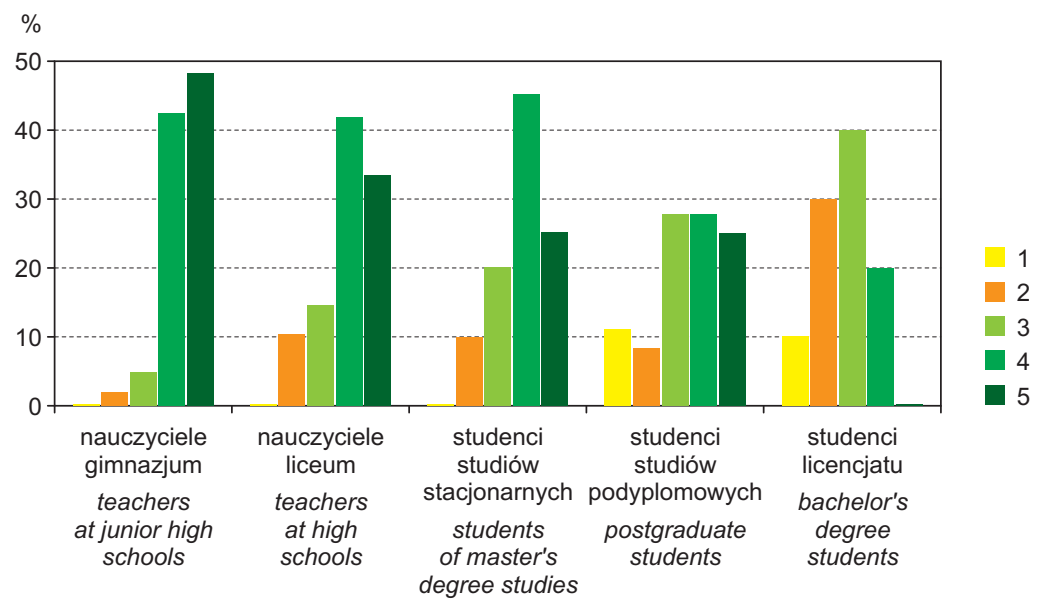

Ryc. 3. Ocena kompetencji w zakresie rozumienia praw ewolucji wszechświata i Ziemi

The assessment of competences in understanding the laws of the evolution of the Earth and the Universe

Źródło/Source: Osuch (2010, s./p. 115).

Wykaz kompetencji dotyczących systemu przyrodniczego Ziemi obejmował kilka szczegółowych umiejętności (zał. 1). Uzyskane oceny wykształcenia tych kompetencji są bardzo zróżnicowane, choć dominują oceny bardzo dobre (5 pkt.) - od około 48\% do 90\% wśród nauczycieli gimnazjum i 25-92 \% wśród nauczycieli liceum. Na przykład, najlepiej nauczyciele ocenili kompetencje obliczania 
średniej rocznej temperatury powietrza oraz amplitudy temperatury (ponad 90\% ocen bardzo dobrych wśród nauczycieli gimnazjum i prawie 92\% liceum), nieco słabiej kompetencje z zakresu analizowania stanu atmosfery i przewidywania jej zmian (31\% ocen dobrych wśród nauczycieli gimnazjum i 42\% liceum).

Znaczne było zróżnicowanie samooceny nabycia kompetencji w zakresie rozpoznawania i klasyfikowania podstawowych minerałów i skał, gdzie aż 35\% ankietowanych nauczycieli gimnazjum uzyskało 4 pkt., a prawie 10\% tylko 3 pkt. (dla porównania 50\% ankietowanych nauczycieli liceum uzyskało 4 pkt., a aż 25\% tylko 3 pkt.). Ten przykład pokazuje, że wielu nauczycieli nie czuje się pewnie w rozpoznawaniu skał. W kwestionariuszach ankiet nie podano precyzyjnie, o które podstawowe minerały i skały chodziło. Można jednak domniemywać, że właśnie tych podstawowych nie potrafi rozpoznać około 45\% nauczycieli gimnazjum i aż 75\% nauczycieli liceum. Wynik ten jest mało optymistyczny. Nabyciu tej umiejętności z pewnością sprzyja zainteresowanie studentów ćwiczeniami z geologii i praktykami przedmiotowymi z geologii, a także praktyczne rozpoznawanie skał na zajęciach dydaktycznych.

Kompetencję analizowania procesów endogenicznych i egzogenicznych modelujących powierzchnię Ziemi (ryc. 4), a więc z zakresu klasycznych kompetencji geomorfologicznych, 40\% nauczycieli gimnazjum nabyło w stopniu dobrym (4 pkt.). Na stopień przynajmniej dobry oceniło tę kompetencję 80\% studentów studiów stacjonarnych, około 60\% studentów licencjatu i tylko 33\% studentów studiów podyplomowych. Nie bez wpływu jest tu zróżnicowanie godzinowe przedmiotu w planach studiów geograficznych.

Grupa kompetencji dotycząca problematyki systemu społeczno-gospodarczego współczesnego świata obejmuje 13 szczegółowych kompetencji (w tab. 1 przedstawiono tylko wybrane). Uzyskane w wyniku badań ankietowych oceny były bardziej zróżnicowane niż w poprzednio analizowanych grupach kompetencji. Ponadto wśród nauczycieli i w prawie wszystkich przykładach oceny bardzo dobre zdecydowanie dominowały nad pozostałymi. Na przykład, najlepsze wyniki uzyskanych kompetencji wśród nauczycieli uzyskano w zakresie obliczania wskaźnika przyrostu naturalnego, salda migracji, przyrostu rzeczywistego oraz wskaźnika feminizacji (zał. 1) - ponad 90\% ocen bardzo dobrych wśród nauczycieli gimnazjum oraz ponad 79\% wśród nauczycieli liceum. Także wśród studentów studiów podyplomowych i studentów licencjatu dominowały oceny dobre, co można tłumaczyć realizacją tych treści na wszystkich rocznikach studiów geograficznych.

Bardzo krytycznie nauczyciele gimnazjum ocenili swoje kompetencje w zakresie logicznego argumentowania za lub przeciw procesom globalizacji (ryc. 5): prawie $20 \%$ ocen dostatecznych (3 pkt.), 35\% dobrych i tylko $42 \%$ bardzo dobrych (prawie 4\% to oceny poniżej 3 pkt.). Wśród nauczycieli liceum uzyskano niecałe 9\% ocen dostatecznych, 37\% dobrych i 54\% bardzo dobrych. Należy zwrócić uwagę, że procesy globalizacji dopiero w ostatnich latach są przedmiotem badań 


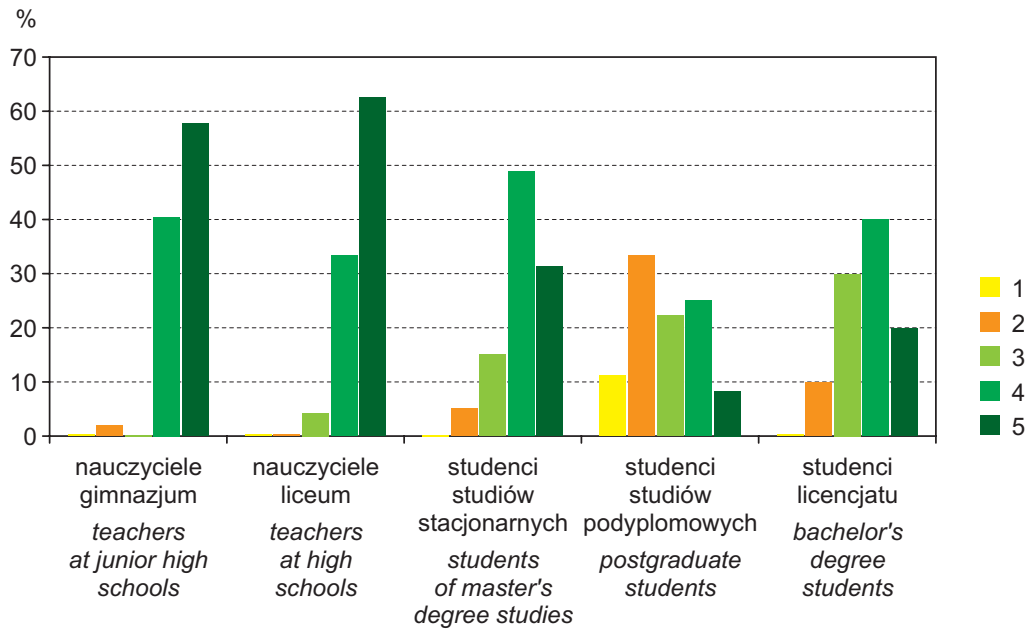

Ryc. 4. Ocena kompetencji w zakresie analizowania procesów endogenicznych i egzogenicznych modelujących powierzchnię Ziemi

The assessment of competences in the ability to analyse the endogenous and exogenous processes which shape the Earth's surface

Źródło/Source: Osuch (2010, s./p. 117).

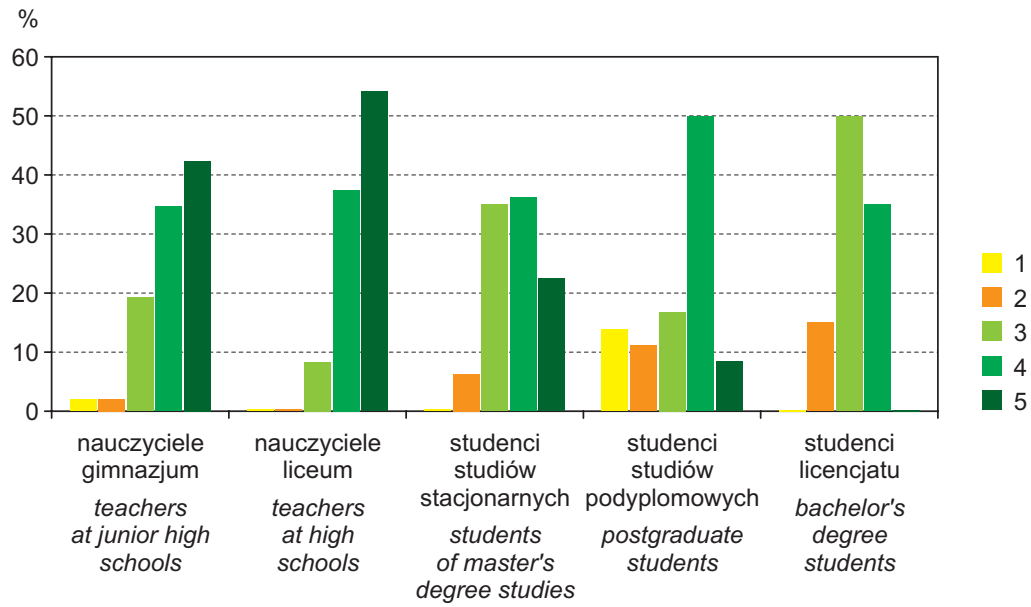

Ryc. 5. Ocena kompetencji w zakresie logicznego argumentowania za lub przeciw procesom globalizacji

The assessment of competences in presenting logical arguments for and against globalisation processes Źródło/Source: Osuch (2010, s./p. 119).

i analiz geografów społeczno-ekonomicznych na szeroką skalę, jak również występują w programach i podręcznikach geografii do liceum i gimnazjum. Spośród badanych studentów najlepsze wyniki uzyskali stacjonarni. 
Uzyskanie wysokich ocen w zakresie prezentowania ugrupowań integracyjnych na świecie oraz konsekwencji procesu integracji stanowiło także dla niektórych nauczycieli gimnazjum pewien problem (podobnie jak dla studentów studiów podyplomowych). Prawie 12\% nauczycieli gimnazjum oceniło tę kompetencję na ocenę dostateczną, około 4\% na 2 pkt., i niespełna 31\% na 4 pkt.; wśród nauczycieli liceum 17\% opanowało tę kompetencję tylko w stopniu dostatecznym, a 50\% na 4 pkt. (zał. 1). Przykład ten pokazuje, że nauczyciele o dłuższym stażu pracy w szkole nie mogli nabyć umiejętności w czasie studiów geograficznych; musieli ją zdobyć we własnym zakresie podczas pracy zawodowej. Studenci studiów stacjonarnych kompetencje z zakresu systemu społeczno-gospodarczego świata współczesnego świata ocenili bardzo dobrze i dobrze. Nieco słabiej wypadły kompetencje w zakresach:

- logicznego argumentowania przemawiającego za lub przeciw procesom globalizacji (tylko 22\% ocen bardzo dobrych, 36\% dobrych i aż 35\% dostatecznych i 6\% dopuszczających);

- prezentowania ugrupowań integracyjnych na świecie i konsekwencji procesu integracji (prawie 39\% ocen dobrych, 25\% dostatecznych i 5\% dopuszczających).

Słabsze wyniki nabycia tych kompetencji należy tłumaczyć trudnymi i niejasnymi argumentami stosowanymi zwłaszcza przez polityków czy dziennikarzy do wyjaśnienia idei procesów globalizacji i nieznanymi często do końca konsekwencjami ich działań.

Grupa kompetencji dotyczących działalności człowieka w środowisku obejmuje pięć szczegółowych kompetencji (w zał. 1 przedstawiono wybrane trzy). Oceny stopnia ich nabycia są zróżnicowane, choć przeważnie bardzo dobre i dobre. Najniżej oceniono kompetencje nauczycieli gimnazjum w zakresie zrozumienia idei rozwoju zrównoważonego (ryc. 6). W tym przypadku 46\% nauczycieli gimnazjum wykształciło tę kompetencję na 5 pkt., prawie 35\% na 4 pkt., około 15\% na ocenę dostateczną (3 pkt.) i prawie 4\% poniżej 3 pkt.

W grupie nauczycieli liceum stopień zrozumienia idei rozwoju zrównoważonego 46\% nauczycieli oceniło na 5 pkt., prawie 35\% na 4 pkt., około 15\% na ocenę dostateczną ( 3 pkt.) i bez mała $4 \%$ poniżej 3 pkt. Pomimo prowadzenia w uczelni zajęć dydaktycznych podejmujących problematykę rozwoju zrównoważonego, a także dyskusji w mediach, nadal zbyt duży wydaje się odsetek nienabytych kompetencji w tym zakresie (ryc. 6). Przypuszczalnie wynika to z niedoprecyzowania, a przez to niezrozumienia definicji pojęcia rozwoju zrównoważonego, a także z różnych jego interpretacji.

Studenci studiów niestacjonarnych uzyskali na ogół niższe oceny w zakresie wykształconych kompetencji.

Kompetencje przedmiotowe studentów geografii są nieznacznie słabiej wykształcone niż w przypadku nauczycieli geografii. Należy mieć na uwadze często wieloletnie doświadczenie zawodowe nauczycieli w szkole, gdzie kom- 
petencje są doskonalone. Dla studentów geografii ważnym, ale nie jedynym źródłem kształtowania kompetencji są zajęcia teoretyczne w uczelni (wykłady, ćwiczenia), rzadziej praktyki terenowe, a praktyka zawodowa w szkole jest zbyt krótka, aby je kształtować, ćwiczyć i doskonalić.

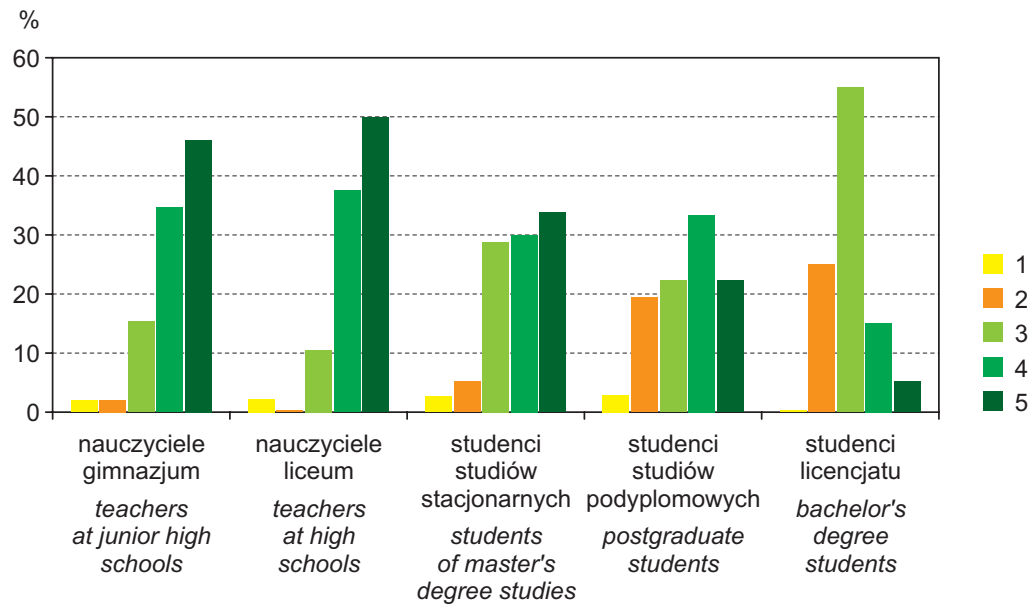

Ryc. 6. Ocena kompetencji w zakresie zrozumienia idei rozwoju zrównoważonego The assessment of competences in understanding the idea of sustainable development Źródło/Source: Osuch (2010, s./p. 121).

Realizowane trzysemestralne studia podyplomowe z geografii, które w świetle obowiązujących przepisów i rozporządzeń dają uprawnienia do nauczania geografii w gimnazjum i w szkole ponadgimnazjalnej, nasuwają wiele pytań i wątpliwości dotyczących kształcenia przyszłych geografów tą drogą, a także kształtowania kompetencji w grupie „przyszłych geografów”. Deklaracja Bolońska zakłada, między innymi, możliwość szybkiego zdobycia dodatkowych uprawnień przez nauczycieli w zakresie nauczania nowego przedmiotu, w tym wypadku geografii. Ocena kompetencji przedmiotowych wśród studentów studiów podyplomowych była przedmiotem analizy w oddzielnej publikacji (Osuch, 2011). Ten typ studiów w Polsce często traktuje się komercyjnie, bo kandydaci oczekują w miarę szybkiego przygotowania do nauczania kolejnego przedmiotu. Prawdopodobnie w przypadku innych przedmiotów nauczania sytuacja wygląda podobnie.

Studia podyplomowe kwalifikacyjne, oprócz uzyskania kwalifikacji w zakresie nauczania dodatkowego przedmiotu są wysoko oceniane podczas odbywania stażu i ubiegania się o wyższy stopień awansu zawodowego (Osuch, 2010). Wydaje się to uzasadnione w sytuacji, kiedy nauczyciel może być bardziej konkurencyjny na rynku pracy. Bywają przypadki, kiedy uzyskany dyplom ukończenia studiów podyplomowych wydaje się nieadekwatny do nabytych kompetencji w tym zakresie. 
Wypełniając część kwestionariusza ankiety dotyczącą kompetencji przedmiotowych zarówno studentów geografii-kandydatów na nauczycieli, jak i nauczycieli geografii, można było uzyskać maksymalnie 200 punktów. Wyniki punktowe w zakresie nabytych kompetencji przedmiotowych w poszczególnych grupach ankietowanych prezentuje rycina 7 .

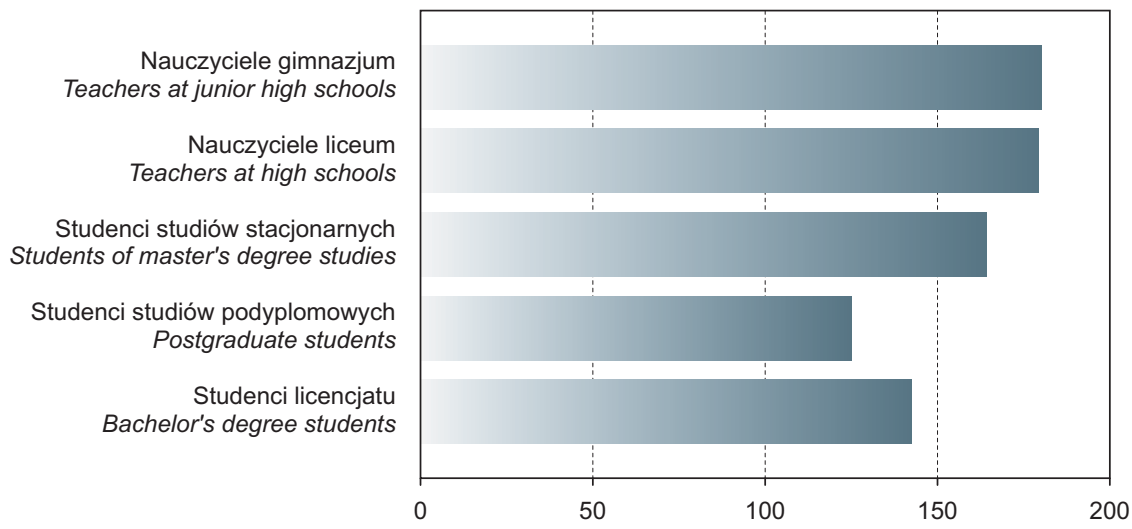

Ryc. 7. Kompetencje przedmiotowe z geografii w skali punktowej Opracowanie własne na podstawie: Osuch (2010).

Acquired subject competences in geography shown on a point scale Author's own elaboration based on: Osuch (2010).

Na podstawie przeprowadzonych badań sformułowano następujące uogólnienia:

- czynni nauczyciele geografii - zarówno w gimnazjum, jak i w liceum - pełniący funkcję opiekunów studenckich praktyk zawodowych uzyskali najwięcej punktów za nabycie konkretnych kompetencji (średnio 180 pkt.);

- relatywnie dobre wyniki (średnio 164 na 200 pkt.) uzyskali studenci geografii jednolitych studiów magisterskich;

- studenci licencjatu studiów niestacjonarnych zdobyli średnio 143 pkt.;

- studenci studiów podyplomowych niestacjonarnych z geografii uzyskali najmniej punktów (średnio 125/200).

Podjęto próbę określenia zależności pomiędzy liczbą uzyskanych punktów w zakresie wykształcenia kompetencji a ocenami (zarówno punktowymi, jak i w stopniach) od studentów geografii, którzy odbywali praktykę zawodową w szkole u tych nauczycieli. W czasie hospitacji studenci dokonali oceny lekcji. Ograniczono się w tym przypadku do zaprezentowania oceny nabycia wyłącznie kompetencji przedmiotowych i sformułowano hipotezę:

>Istnieje związek pomiędzy sumą punktów opisujących nauczyciela w zakresie jego kompetencji przedmiotowych z geografii a oceną kompetencji 
tego nauczyciela dokonanej, przez studenta-praktykanta podczas hospitacji na lekcji geografii.<

Korelacje policzono dla pięciu grup nauczycieli - opiekunów praktyk studentów geografii:

a) nauczycieli gimnazjum - opiekunów studentów niestacjonarnych,

b) nauczycieli szkół ponadgimnazjalnych (najczęściej liceum),

c) nauczycieli gimnazjum,

d) nauczycieli gimnazjum i liceum (suma b+c),

e) wszystkich nauczycieli (suma $a+b+c)$.

Należy zaznaczyć, że we wszystkich przykładach z wyjątkiem pkt. a, praktyki dotyczyły studentów studiów stacjonarnych.

Ad a). Wyliczono korelację $r=0,27$ przy wartości krytycznej $r_{\alpha}=0,20$; to oznacza, że korelacja jest istotna, ale stosunkowo słaba pomiędzy sumą punktów uzyskanych przez nauczyciela gimnazjum oraz oceną kompetencji nauczyciela przez studenta geografii studiów niestacjonarnych. Korelacja dodatnia oznacza, że im więcej punktów nauczyciel geografii przyznał sobie w zakresie wykształcenia kompetencji przedmiotowych z geografii, tym wyższą też ocenę uzyskał od studentów. Uzyskany wynik świadczyć może o prawidłowości, że doświadczony nauczyciel z solidną wiedzą i umiejętnościami geograficznymi dysponuje kompetencjami, dzięki którym prowadzi lekcje zarówno efektywne, jak i efektowne w oczach oceniających go studentów studiów niestacjonarnych.

Ad b). Wyliczono korelację $r=0,24$ przy wartości krytycznej $r_{\alpha}=0,18$, zatem jest istotna, choć słaba dodatnia korelacja pomiędzy wiedzą i umiejętnościami geograficznymi nauczycieli w liceum a oceną ich kompetencji przez studenta geografii studiów stacjonarnych. Nauczyciele geografii w liceum dysponujący wiedzą i umiejętnościami geograficznymi zostali wysoko ocenieni przez studentów.

Ad c). Wyliczono korelację $r=0,31$ przy wartości krytycznej $r_{\alpha}=0,14$, czyli zależność jak wyżej sprawdza się także w przypadku nauczycieli w gimnazjum.

Ad d). Wyliczono korelację $r=0,26$ przy wartości krytycznej $r_{\alpha}=0,11$, co oznacza, że również w przypadku nauczycieli w gimnazjum i liceum (suma $\mathrm{b}+\mathrm{c})$, jest istotna korelacja między samooceną a oceną kompetencji nauczyciela wystawioną przez studentów.

Ad e). Wyliczono korelację $r=0,28$ przy wartości krytycznej $r_{\alpha}=0,09$ dla wszystkich nauczycieli geografii uczestniczących w badaniach (suma $a+b+c)$; jest istotna korelacja pomiędzy samooceną w zakresie wykształconych kompetencji przedmiotowych z geografii, a oceną kompetencji nauczyciela uzyskaną od studentów.

Można zatem stwierdzić, że im więcej kompetencji nauczyciel wykształcił (miał większą wiedzę geograficzną i umiejętności geograficzne), tym wyższą 
ocenę uzyskał za kompetencje zaprezentowane na lekcji geografii (Osuch, 2010a). Studenci geografii nie mieli dostępu do ocen punktowych nauczycieli.

$\mathrm{Na}$ podstawie badań udowodniono, że związek między zdobytą wiedzą geograficzną i wykształconymi umiejętnościami przedmiotowymi z geografii a sukcesem w zaprezentowaniu swoich kompetencji i prowadzeniu efektywnej lekcji geografii w szkole jest istotny statystycznie. Ponadto studenci geografiikandydaci na nauczycieli analizowanych roczników studiów potrafią rozpoznać wśród nauczycieli-opiekunów praktyk poziom kompetencji przedmiotowych z geografii.

Wyniki badań korelacji pomiędzy wykształceniem kompetencji przedmiotowych z geografii a kompetencjami prezentowanymi przez nauczyciela na lekcji geografii mogą stanowić sugerować dalsze badania z tego zakresu. Kontynuacja badań może przyczynić się do optymalizacji procesu kształcenia nauczycieli (w tym nauczycieli geografii) oraz do wypracowania skutecznego i efektywnego modelu kształcenia przyszłych nauczycieli.

\section{Piśmiennictwo}

De Jong H., 2008, Aspekte der Ausbildung von Geographielehrer/inne/n In den Niederlanden, Geographie und Wirtschaftskunde Unterricht, 109, Wien, s. 27-32.

Erpenbeck J., Rosenstiel L. (red.), 2003, Handbuch Kompetenzmessung, Schäffer-Poeschl, Stuttgart.

Greń J., 1974, Statystyka matematyczna. Modele i zadania, PWN, Warszawa.

Kyriacou Ch., 1991, Essentials Teaching Skills, Blackwell, Oxford.

Kwiatkowska H., 2008, Pedeutologia, Wydawnictwa Akademickie i Profesjonalne, Warszawa.

Okoń W., 2001, Nowy stownik pedagogiczny, Wydawnictwo Akademickie Żak, Warszawa.

Osuch W., 2010, Kompetencje nauczycieli geografii oraz studentów geografii-kandydatów na nauczycieli, Prace Monograficzne, 570, Wydawnictwo Uniwersytetu Pedagogicznego w Krakowie, Kraków.

-, 2011, Efektywność akademickiego ksztatcenia kompetencji na studiach podyplomowych z geografii (na przyktadzie Uniwersytetu Pedagogicznego w Krakowie), [w:] E. Szkurłat, M. Tracz (red.), Efekty ksztatcenia geograficznego na różnych poziomach nauczania, Prace Komisji Edukacji Geograficznej PTG, 1, Poligrafia Inspektoratu Towarzystwa Salezjańskiego, Kraków, s. 162-170.

Průcha J., 2006, Pedeutologia, [w:] B. Śliwerski (red.), Pedagogika. Pedagogika wobec edukacji, polityki oświatowej i badań naukowych, t. 2, Gdańskie Wydawnictwo Pedagogiczne, Gdańsk, s. 293-316.

Rozporządzenie Ministra Edukacji Narodowej i Sportu z 7 września 2004 r. w sprawie standardów kształcenia, Dz.U. 2004, nr 207, poz. 2110.

Vielhaber Ch., 2006, Wie viel Nachhaltigkeit verträgt das Schulfach Geographie und Wirtschaftskunde? Unterricht, 103, Wien, s. 17-24.

-, 2008, Standards und/ oder kompetenzen im GW-Unterricht? GW Unterricht, 110, Wien, s. 1-6.

[Wpłynęło: styczeń; poprawiono: kwiecień 2011 r.] 
WIKTOR OSUCH

\section{THE ASSESSMENT OF SELECTED SUBJECT COMPETENCES ACQUIRED BY GEOGRAPHY TEACHERS AND STUDENT-CANDIDATES FOR TEACHING POSTS}

For many years now, Poland has resembled many other European countries in playing host to an active search for solutions when it comes to ensuring proper conditions for young people to develop their interests, broaden their horizons and receive the education that will assure them of high-level competences, and hence a competitive presence on a constantly-changing European job market. Such circumstances pose an enormous challenge to the educational system and the teachers working within it, who will be required to implement solutions accepted, but also obviously influence further change. While Poland has passed through a period of many and varied trials when it comes to the introduction of different changes in the educational system (involving everything from types of school, through levels of teaching, changes in curricula for each school subject, syllabuses and textbooks, all the way through to the modification of teaching aims and content for each subject), very little has in fact been done to promote the necessary remodelling work that would ensure the shaping of a truly modern teacher.

In the process of teacher-training, including that offered to would-be geography teachers, a crucial role is played by competences mainly developed in the course of studies, as well as in the course of internships in schools. In fact, the author of this article has been researching the matter of this process of acquisition of subject and didactic competence by geography teacher-trainees for over ten years now. It is his experience that, while the acquired degree of professional advancement is obviously an important criterion when it comes to the assessment of a teacher's work, it does not in practice offer a true reflection of the level of skill a teacher has come to possess. Since these competences too are in genuine need of assessment, and since that assessment may not be performed by pupils (being neither sufficiently careful nor sufficiently objective in these circumstances), the author proposes that the teachers be assessed in their role as teacher-training mentors, by students who were under their supervision in the course of their vocational training. The author further proposes a procedure of self-assessment for teachers, again assuming that this is capable of being both careful and objective.

The aim of the research work presented in this paper has thus been to achieve a comprehensive evaluation of competences acquired by active geography teachers (and supervisors of students' internships in given schools) and by geography students, a multiaspectual analysis of factors affecting the process of competence development in geography teacher-trainees, and the creation of a model for teachers' competence evaluations by geography students.

Didactic competence research was conducted by means of the diagnostic poll (survey) method. The applied research tools were four questionnaires, containing mostly closed (single-choice or multiple-choice) questions. Surveying work was conducted among 96 geography teachers (in the years 2008 and 2009), graduates in the teaching faculty of the geography studies department at the Pedagogical University (ex Pedagogical Academy) in Kraków, the Jagiellonian University in Krakow, and also - in individual cases - graduates from the University of Silesia in Katowice, the Nicolaus Copernicus 
University in Torun and the Maria Curie Skłodowska University in Lublin. In addition, for comparative purposes, 136 geography students from three different faculties of studies at the Pedagogical University of Kraków also took part in the survey.

The presented research is an attempt to find the relationship between the received points given for the development of competences and the assessment performed both in points and marks given by geography students who did vocational teaching training with geography teachers as their mentors at school.

The Student $t$ distribution with n-2 degrees of freedom was used to calculate the correlation between the examined variables, and the observed value for the coefficient of the linear correlation $r$ was also compared with the critical value calculated by means of a formula. The free computer program Mathematica 5.2 (for student) Wolframa was used to calculate the correlation.

On the basis of the research conducted, it proved possible to formulate the following conclusions and generalisations:

- the level of subject competence in geography influences the evaluation of a teacher's competence presented in the geography class, which is to say that subject competence in geography is definitely associated most frequently with success in the class;

- geography students of all examined year-groups are able to recognise the level of subject competence of teacher as school internship supervisors, and are able to conduct a thorough and objective evaluation of a geography class.

On the basis of the conducted research, other conclusions relating to competence in geography as a whole were formulated:

- it was mostly in theoretical classes at university that geography teachers acquired subject competence in geography;

- the majority of full-time students see theoretical classes at the university as the source of subject competence in geography;

- subject-related and region-related field exercises are the most important complement to theoretical classes when it comes to students' developing subject competence in geography.

The presented research results should serve as an impulse for further analyses, as well as as a reflection on the development of competence in teacher-trainees. Research in this area should contribute to optimisation of the teacher-training process, including for geography teachers (and not only in Poland), but also to the development of an effective and efficient model for teacher-training and competence acquisition. 
Ocena nabycia wybranych kompetencji przedmiotowych z geografii przez nauczycieli i studentów geografii

Assessment of the acquisition of selected subject competences in geography by teachers and students thereof

\begin{tabular}{|c|c|c|c|c|c|c|c|c|c|c|c|}
\hline \multirow{3}{*}{$\begin{array}{l}\text { Zakres wybranych kompetencji } \\
\text { przedmiotowych z geografii } \\
\text { Scope of selected subject } \\
\text { competences in geography }\end{array}$} & \multirow{3}{*}{$\begin{array}{l}\text { Ankie- } \\
\text { towana } \\
\text { grupa } \\
\text { Survey- } \\
\text { ed group }\end{array}$} & \multicolumn{10}{|c|}{$\begin{array}{l}\text { Ocena kompetencji w skali od } 1 \text { do } 5 \\
\text { Assessed competence on a scale from } 1 \text { to } 5\end{array}$} \\
\hline & & \multicolumn{2}{|c|}{1} & \multicolumn{2}{|c|}{2} & \multicolumn{2}{|c|}{3} & \multicolumn{2}{|c|}{4} & \multicolumn{2}{|c|}{5} \\
\hline & & $\begin{array}{l}\text { liczba } \\
\text { number }\end{array}$ & $\%$ & $\begin{array}{l}\text { liczba } \\
\text { number }\end{array}$ & $\%$ & $\begin{array}{l}\text { liczba } \\
\text { number }\end{array}$ & $\%$ & $\begin{array}{l}\text { liczba } \\
\text { number }\end{array}$ & $\%$ & $\begin{array}{l}\text { liczba } \\
\text { number }\end{array}$ & $\%$ \\
\hline \multicolumn{12}{|c|}{ I. Mapa źródłem informacji geograficznej / The map as a source of geographical information } \\
\hline \multirow{5}{*}{$\begin{array}{l}\text { 1. Orientowanie mapy } \\
\text { Orienting a map }\end{array}$} & $\mathrm{ng}$ & 0 & 0 & 0 & 0 & 2 & 3,8 & 4 & 7,7 & 46 & 88,5 \\
\hline & $\mathrm{nl}$ & 0 & 0 & 0 & 0 & 2 & 4,2 & 8 & 16,6 & 38 & 79,2 \\
\hline & $\mathrm{sm}$ & 1 & 1,25 & 0 & 0 & 5 & 6,25 & 20 & 25,0 & 54 & 67,5 \\
\hline & sp & 2 & 5,5 & 4 & 11,1 & 3 & 8,3 & 14 & 38,9 & 13 & 36,2 \\
\hline & sl & 0 & 0 & 0 & 0 & 6 & 30,0 & 8 & 40,0 & 6 & 30,0 \\
\hline \multirow{5}{*}{$\begin{array}{l}\text { 2. Obliczanie na podstawie map: odległości, } \\
\text { powierzchni, skali } \\
\text { Using a map to calculate distances, sizes } \\
\text { and scales }\end{array}$} & $\mathrm{ng}$ & 0 & 0 & 1 & 1,9 & 1 & 1,9 & 8 & 15,3 & 42 & 80,8 \\
\hline & $\mathrm{nl}$ & 0 & 0 & 0 & 0 & 0 & 0 & 4 & 8,3 & 44 & 91,7 \\
\hline & $\mathrm{sm}$ & 0 & 0 & 0 & 0 & 5 & 6,25 & 22 & 27,5 & 53 & 66,2 \\
\hline & $\mathrm{sp}$ & 3 & 8,3 & 6 & 16,6 & 6 & 16,6 & 11 & 30,6 & 10 & 27,8 \\
\hline & $\mathrm{sl}$ & 0 & 0 & 0 & 0 & 5 & 25,0 & 8 & 40,0 & 7 & 35,0 \\
\hline \multirow{5}{*}{$\begin{array}{l}\text { 3. Rysowanie planów, szkiców i profili } \\
\text { terenowych } \\
\text { Preparation of field plans, sketches } \\
\text { and profiles }\end{array}$} & ng & 1 & 1,9 & 1 & 1,9 & 5 & 9,6 & 18 & 34,6 & 27 & 51,9 \\
\hline & $\mathrm{nl}$ & 0 & 0 & 0 & 0 & 6 & 12,5 & 22 & 45,8 & 20 & 41,7 \\
\hline & $\mathrm{sm}$ & 1 & 1,25 & 4 & 5,0 & 13 & 16,25 & 38 & 47,5 & 24 & 30,0 \\
\hline & $\mathrm{sp}$ & 12 & 33,3 & 6 & 16,6 & 7 & 19,4 & 7 & 19,4 & 4 & 11,1 \\
\hline & $\mathrm{sl}$ & 0 & 0 & 2 & 10,0 & 2 & 10,0 & 11 & 55,0 & 5 & 25,0 \\
\hline
\end{tabular}

\section{Astronomiczne podstawy geografii / The astronomical bases to geography}

\begin{tabular}{|c|c|c|c|c|c|c|c|c|c|c|c|}
\hline \multirow{3}{*}{$\begin{array}{l}\text { 1. Wykonywanie rysunków przedstawiających } \\
\text { widome drogi Słońca nad horyzontem w róż- } \\
\text { nych szerokościach geograficznych }\end{array}$} & $\mathrm{ng}$ & 0 & 0 & 1 & 1,9 & 3 & 5,8 & 16 & 30,8 & 32 & 61,5 \\
\hline & $\mathrm{nl}$ & 1 & 1,2 & 2 & 4,2 & 6 & 12,5 & 16 & 33,3 & 23 & 47,9 \\
\hline & $\mathrm{sm}$ & 0 & 0 & 14 & 17,5 & 18 & 22,5 & 30 & 37,5 & 18 & 22,5 \\
\hline \multirow{2}{*}{$\begin{array}{l}\text { Preparation of diagrams presenting the path } \\
\text { the Sun appears to take above the horizon at } \\
\text { different latitudes }\end{array}$} & $\mathrm{sp}$ & 13 & 36,1 & 7 & 19,4 & 6 & 16,6 & 7 & 19,4 & 3 & 8,3 \\
\hline & $\mathrm{sl}$ & 0 & 0 & 12 & 60,0 & 6 & 30,0 & 2 & 10,0 & 0 & 0 \\
\hline \multirow{5}{*}{$\begin{array}{l}\text { 2. Rozumienie praw ewolucji Wszechświata } \\
\text { i Ziemi } \\
\text { Understanding the laws underpinning the } \\
\text { evolution of the universe and the Earth }\end{array}$} & ng & 0 & 0 & 1 & 1,9 & 4 & 7,7 & 22 & 42,3 & 25 & 48,1 \\
\hline & $\mathrm{nl}$ & 0 & 0 & 5 & 10,4 & 7 & 14,6 & 20 & 41,7 & 16 & 33,3 \\
\hline & $\mathrm{sm}$ & 0 & 0 & 8 & 10,0 & 16 & 20,0 & 36 & 45,0 & 20 & 25,0 \\
\hline & $\mathrm{sp}$ & 4 & 11,1 & 3 & 8,3 & 10 & 27,7 & 10 & 27,7 & 9 & 25,0 \\
\hline & $\mathrm{sl}$ & 2 & 10,0 & 6 & 30,0 & 8 & 40,0 & 4 & 20,0 & 0 & 0 \\
\hline
\end{tabular}

III. System przyrodniczy Ziemi / The Earth's natural system

\begin{tabular}{|c|c|c|c|c|c|c|c|c|c|c|c|}
\hline \multirow{5}{*}{$\begin{array}{l}\text { 1. Obliczanie średniej rocznej temperatury } \\
\text { powietrza oraz amplitudy temperatury } \\
\text { Calculation of mean annual air temperature } \\
\text { and temperature amplitude }\end{array}$} & $\mathrm{ng}$ & 0 & 0 & 0 & 0 & 1 & 1,9 & 4 & 7,7 & 47 & 90,4 \\
\hline & $\mathrm{nl}$ & 0 & 0 & 0 & 0 & 0 & 0 & 4 & 8,3 & 44 & 91,7 \\
\hline & $\mathrm{sm}$ & 0 & 0 & 0 & 0 & 2 & 2,5 & 12 & 15,0 & 66 & 82,5 \\
\hline & $\mathrm{sp}$ & 1 & 2,8 & 1 & 2,8 & 6 & 16,6 & 13 & 36,1 & 15 & 41,7 \\
\hline & sl & 0 & 0 & 0 & 0 & 2 & 10,0 & 6 & 30,0 & 12 & 60,0 \\
\hline \multirow{5}{*}{$\begin{array}{l}\text { 2. Analizowanie stanu atmosfery i przewidywa- } \\
\text { nie jego zmian } \\
\text { Analysis of the state of the atmosphere and } \\
\text { anticipated changes thereto }\end{array}$} & $\mathrm{ng}$ & 0 & 0 & 0 & 0 & 2 & 3,8 & 16 & 30,8 & 34 & 65,4 \\
\hline & $\mathrm{nl}$ & 0 & 0 & 0 & 0 & 8 & 16,6 & 20 & 41,7 & 20 & 41,7 \\
\hline & $\mathrm{sm}$ & 0 & 0 & 5 & 6,2 & 15 & 18,75 & 28 & 35,0 & 32 & 40,0 \\
\hline & $\mathrm{sp}$ & 0 & 0 & 1 & 2,8 & 10 & 27,7 & 18 & 50,0 & 7 & 19,4 \\
\hline & $\mathrm{sl}$ & 0 & 0 & 0 & 0 & 6 & 30,0 & 8 & 40,0 & 6 & 30,0 \\
\hline \multirow{5}{*}{$\begin{array}{l}\text { 3. Rozpoznawanie i klasyfikowanie podstawo- } \\
\text { wych minerałów i skał } \\
\text { Recognition and classification of main } \\
\text { minerals and rocks }\end{array}$} & $\mathrm{ng}$ & 0 & 0 & 0 & 0 & 5 & 9,6 & 18 & 34,6 & 29 & 55,8 \\
\hline & $\mathrm{nl}$ & 0 & 0 & 0 & 0 & 12 & 25,0 & 24 & 50,0 & 12 & 25,0 \\
\hline & $\mathrm{sm}$ & 0 & 0 & 3 & 3,8 & 14 & 17,5 & 30 & 37,5 & 33 & 41,25 \\
\hline & $\mathrm{sp}$ & 0 & 0 & 0 & 0 & 12 & 33,3 & 12 & 33,3 & 12 & 33,3 \\
\hline & $\mathrm{sl}$ & 0 & 0 & 0 & 0 & 6 & 30,0 & 12 & 60,0 & 2 & 10,0 \\
\hline \multirow{5}{*}{$\begin{array}{l}\text { 4. Analizowanie procesów endo- i egzogenicz- } \\
\text { nych modelujących powierzchnię Ziemi } \\
\text { Analysing endogenous and exogenous } \\
\text { processes modelling the Earth's surface }\end{array}$} & ng & 0 & 0 & 1 & 1,9 & 0 & 0 & 21 & 40,4 & 30 & 57,7 \\
\hline & $\mathrm{nl}$ & 0 & 0 & 0 & 0 & 2 & 4,2 & 16 & 33,3 & 30 & 62,5 \\
\hline & $\mathrm{sm}$ & 0 & 0 & 4 & 5,0 & 12 & 15,0 & 39 & 48,8 & 25 & 31,2 \\
\hline & $\mathrm{sp}$ & 4 & 11,1 & 12 & 33,3 & 8 & 22,2 & 9 & 25,0 & 3 & 8,3 \\
\hline & $\mathrm{sl}$ & 0 & 0 & 2 & 10,0 & 6 & 30,0 & 8 & 40,0 & 4 & 20,0 \\
\hline
\end{tabular}

IV. System społeczno-gospodarczy współczesnego świata / The contemporary world's socioeconomic system

\begin{tabular}{|c|c|c|c|c|c|c|c|c|c|c|c|}
\hline 1. Obliczanie wskaźnika przyrostu naturalnego. & $\mathrm{ng}$ & 0 & 0 & 0 & 0 & 0 & 0 & 5 & 9,6 & 47 & $\mathbf{9 0 , 4}$ \\
\cline { 2 - 18 } & & & 0 & 0 & 0 & 0 & 0 & 0 & 38 & 79,2 \\
\hline
\end{tabular} salda migracji. przyrostu rzeczywistego oraz wskaźnika feminizacji

Calculation of index of natural population growth. migration balance. real growth and feminisation index

2. Logiczne argumentowanie za/przeciw procesom globalizacji

Logical argumentation for and against globalisation processes

\begin{tabular}{|l|c|c|c|c|c|c|c|c|c|c|c|} 
& $\mathrm{sl}$ & 0 & 0 & 3 & 15,0 & 10 & $\mathbf{5 0 , 0}$ & 7 & 35,0 & 0 & 0 \\
\hline & $\mathrm{ng}$ & 0 & 0 & 2 & 3,8 & 6 & 11,5 & 16 & 30,8 & 28 & $\mathbf{5 3 , 8}$ \\
\hline $\begin{array}{l}\text { 3. Prezentowanie ugrupowań integracyjnych } \\
\text { na swiecie. Konsekwencje procesu integracji }\end{array}$ & $\mathrm{nl}$ & 0 & 0 & 0 & 0 & 8 & 16,7 & 24 & $\mathbf{5 0 , 0}$ & 16 & 33,3 \\
\cline { 2 - 12 } $\begin{array}{l}\text { The presentation of integrating groupings } \\
\text { in the world. Consequences of the integration } \\
\text { process }\end{array}$ & $\mathrm{sm}$ & 1 & 1,2 & 4 & 5,0 & 20 & 25,0 & 31 & $\mathbf{3 8 , 7 5}$ & 24 & 30,0 \\
\cline { 2 - 13 } & $\mathrm{sp}$ & 7 & 19,4 & 7 & 19,4 & 3 & 8,3 & 16 & $\mathbf{4 4 , 4}$ & 3 & 8,3 \\
\cline { 2 - 12 } & $\mathrm{sl}$ & 4 & 20,0 & 5 & 25,0 & 7 & $\mathbf{3 5 , 0}$ & 4 & 20,0 & 0 & 0 \\
\hline
\end{tabular}

\section{v. Człowiek w środowisku / Humankind and the environment}

\begin{tabular}{|c|c|c|c|c|c|c|c|c|c|c|c|}
\hline \multirow{5}{*}{$\begin{array}{l}\text { 1. Planowanie inicjatyw mających na celu } \\
\text { ograniczenie zagrożeń ekologicznych } \\
\text { The planning of initiatives that seek to limit } \\
\text { environmental threats }\end{array}$} & ng & 0 & 0 & 2 & 3,8 & 0 & 0 & 24 & 46,1 & 26 & 50,0 \\
\hline & $\mathrm{nl}$ & 0 & 0 & 1 & 2,1 & 14 & 29,2 & 15 & 31,3 & 18 & 37,4 \\
\hline & $\mathrm{sm}$ & 1 & 1,2 & 4 & 5,0 & 32 & 40,0 & 27 & 33,85 & 16 & 20,0 \\
\hline & $\mathrm{sp}$ & 0 & 0 & 1 & 2,8 & 6 & 16,6 & 16 & 44,4 & 13 & 36,1 \\
\hline & sl & 0 & 0 & 1 & 5,0 & 8 & 40,0 & 9 & 45,0 & 2 & 10,0 \\
\hline \multirow{5}{*}{$\begin{array}{l}\text { 2. Prognozowanie stanu środowiska przyrodni- } \\
\text { czego poszczególnych obszarów } \\
\text { Forecast state of the natural environment } \\
\text { in particular areas }\end{array}$} & $\mathrm{ng}$ & 0 & 0 & 2 & 3,8 & 2 & 3,8 & 22 & 42,3 & 24 & 46,1 \\
\hline & $\mathrm{nl}$ & 1 & 2,1 & 2 & 4,2 & 8 & 16,7 & 21 & 43,7 & 16 & 33,3 \\
\hline & $\mathrm{sm}$ & 1 & 1,2 & 10 & 12,5 & 31 & 38,8 & 26 & 32,5 & 12 & 15,0 \\
\hline & $\mathrm{sp}$ & 0 & 0 & 1 & 2,8 & 12 & 33,3 & 15 & 41,6 & 8 & 22,2 \\
\hline & $\mathrm{sl}$ & 0 & 0 & 5 & 25,0 & 8 & 40,0 & 6 & 30,0 & 1 & 5,0 \\
\hline \multirow{5}{*}{$\begin{array}{l}\text { 3. Zrozumienie idei rozwoju zrównoważonego } \\
\text { Understanding of the sustainable develop- } \\
\text { ment concept }\end{array}$} & $\mathrm{ng}$ & 1 & 1,9 & 1 & 1,9 & 8 & 15,3 & 18 & 34,6 & 24 & 46,1 \\
\hline & $\mathrm{nl}$ & 1 & 2,1 & 0 & 0 & 5 & 10,4 & 18 & 37,5 & 24 & 50,0 \\
\hline & sm & 2 & 2,5 & 4 & 5,0 & 23 & 28,8 & 24 & 30,0 & 27 & 33,75 \\
\hline & $\mathrm{sp}$ & 1 & 2,8 & 7 & 19,4 & 8 & 22,2 & 12 & 33,3 & 8 & 22,2 \\
\hline & $\mathrm{sl}$ & 0 & 0 & 5 & 25,0 & 11 & 55,0 & 3 & 15,0 & 1 & 5,0 \\
\hline
\end{tabular}

ng - nauczyciele gimnazjum / teachers at junior high schools; nl - nauczyciele liceum / teachers at high schools; sm - studenci stacjonarni (studia magisterskie) / student of intramural (master's degree) studies; sp - studenci podyplomowi / postgraduate students; sl - studenci licencjatu / bachelor's degree students.

Zródło/Source: Osuch (2010, s./p. 251-261). 